\author{
Aleksandra Nowosad \\ Uniwersytet Marii Curie-Skłodowskiej w Lublinie, Polska \\ ORCID: 0000-0002-9657-680X \\ aleksandra.nowosad@umcs.pl
}

\title{
Glosa do wyroku Trybunału Konstytucyjnego z dnia 11 czerwca 2019 r. (P 20/17, OTK-A 2019, poz. 29)
}

\author{
Gloss to the Judgement of the Constitutional Tribunal \\ of 11 June 2019 (P 20/17, OTK-A 2019, Item 29)
}

\section{STRESZCZENIE}

Autorka podziela stanowisko Trybunału Konstytucyjnego, że art. $87 \S 1$ k.k. w zakresie, w jakim nakłada na sąd obowiązek połączenia kar pozbawienia wolności i ograniczenia wolności oraz wymierzenia kary łącznej pozbawienia wolności po dokonaniu zamiany kary ograniczenia wolności na karę pozbawienia wolności, jest niezgodny z Konstytucją RP. Dodatkowo poruszono problem ratio legis art. 87 k.k. i wskazano, dlaczego tak późno w orzecznictwie zostały dostrzeżone mankamenty regulacji.

Słowa kluczowe: kara ograniczenia wolności; kara pozbawienia wolności; sekwencja kar; kara łączna; wyrok łączny; zbieg przestępstw

W glosowanym orzeczeniu Trybunał Konstytucyjny uznał, że art. $87 \S 1$ k.k. w zakresie, w jakim nakłada na sąd obowiązek połączenia kar pozbawienia wolności i ograniczenia wolności oraz wymierzenia kary łącznej pozbawienia wolności po dokonaniu zamiany kary ograniczenia wolności na karę pozbawienia wolności, jest niezgodny z art. 45 ust. 1 i art. 175 ust. 1 Konstytucji Rzeczypospolitej Polskiej. Wyrok zasługuje na aprobatę.

Przepis art. 87 § 1 k.k. reguluje sytuację, gdy sprawca został skazany za zbiegające się przestępstwa na kary pozbawienia wolności i ograniczenia wolności. Art. $87 \S 1$ k.k. nakazuje zamienić wymierzoną karę/kary ograniczenia wolności na karę pozbawienia wolności. Przy zamianie przyjmuje się, że miesiąc ograniczenia wolności równa się 15 dniom pozbawienia wolności. Po zamianie kary ograniczenia 
wolności na karę pozbawienia wolności należy wymierzyć karę łączną pozbawienia wolności według reguł z art. 86 k.k. ${ }^{1}$

Do art. 87 k.k. dodano nowelą lipcową z 2015 r. paragraf drugi². Przepis $\S 2$ przewiduje, że gdy za zbiegające się przestępstwa wymierzono kary pozbawienia wolności i ograniczenia wolności i kara łączna pozbawienia wolności nie przekroczyłaby 6 miesięcy, a kara łączna ograniczenia wolności nie przekroczyłaby 2 lat, to można orzec te kary łączne jednocześnie. Regulacja z $§ 2$ art. 87 k.k. stanowi wyjątek od reguły z art. $87 \S 1$ k.k. i ma charakter fakultatywny. Można ją zastosować, jeżeli spełnione są określone przesłanki o charakterze formalnym i materialnym. Przesłanki formalne w postaci maksymalnych progów określonych kar są dość rygorystyczne i w wielu sprawach zastosowanie art. $87 \S 2$ k.k. jest w ogóle wykluczone od samego początku (np. wtedy, gdy jedna z kar podlegających łączeniu przekracza 6 miesięcy pozbawienia wolności). W sprawach, w których formalnie nie jest wyłączone zastosowanie przepisu, sąd musi rozważyć, czy cele kary spełni kara łączna nieprzekraczająca 6 miesięcy pozbawienia wolności. Jeżeli nie są spełnione rygorystyczne wymogi formalne (które ab initio mogą wyłączyć możliwość zastosowania $\S 2 \mathrm{w}$ wielu sprawach) lub materialne, sąd musi zastosować $\S 1$ art. 87 k.k., który nakazuje zamianę kar i wymierzenie kary łącznej pozbawienia wolności. Wobec wprowadzenia wyjątku z $\S 2$ regulacja $\mathrm{z}$ art. 87 $\S 1$ k.k. określana jest jako względnie obligatoryjna ${ }^{3}$.

Trybunał Konstytucyjny prawidłowo ustalił zawartość normatywną art. 87 $\S 1$ k.k. Przepis nakłada na sąd obowiązek zamiany kary ograniczenia wolności na karę pozbawienia wolności i wymierzenia jako kary łącznej kary pozbawienia wolności.

1 Zob. P. Kardas, [w:] Kodeks karny. Część ogólna, t. 1: Komentarz do art. 53-116, red. W. Wróbel, A. Zoll, Warszawa 2016, s. 589; wyrok SN z dnia 2 września 1975 r., IV KRN 52/75, OSNKW 1976, nr 3, poz. 44.

2 Art. 87 k.k. zmieniony został przez art. 1 pkt 49 ustawy z dnia 20 lutego 2015 r. o zmianie ustawy - Kodeks karny oraz niektórych innych ustaw (Dz.U. 2015, poz. 396) zmieniającej m.in. ustawę z dniem 1 lipca 2015 r. w ten sposób, że dotychczasowy art. 87 został oznaczony jako § 1 i dodano $\S 2$. Dodanie $\S 2$ wiązało się z wprowadzeniem do Kodeksu karnego sekwencji kar z art. 37b.

3 Tak P. Kardas ([w:] Kodeks karny. Część ogólna, t. 1, s. 585), który wskazuje: „,...] z uwagi na treść art. $87 \S 2$ zasada wymiaru kary łącznej pozbawienia wolności, w wypadku gdy podstawą jej orzeczenia są wymierzone za zbiegające się przestępstwa kary pozbawienia wolności oraz ograniczenia wolności, ma obecnie charakter względnie obligatoryjny, tzn. znajduje zastosowanie wówczas, gdy nie istnieją formalne przesłanki orzeczenia jednocześnie kar łącznych pozbawienia wolności oraz ograniczenia wolności przewidziane w art. 87 § lub gdy mimo istnienia formalnych przesłanek orzeczenia jednocześnie kar łącznych pozbawienia wolności oraz ograniczenia wolności sąd, kierując się dyrektywami wymiaru kary łącznej, nie decyduje się na ich orzeczenie, uznając, że orzeczenie sekwencji kar łącznych nie gwarantowałoby osiągnięcia celów kary”. Zob. także: J. Majewski, Kodeks karny. Komentarz do zmian 2015, Warszawa 2015, s. 322. 
W związku z treścią pytań prawnych Trybunał Konstytucyjny nie badał konstytucyjności całego art. 87 k.k., lecz jedynie konstytucyjność art. 87 § 1 k.k. w aspekcie obligatoryjności stosowania mechanizmu przewidzianego w tym przepisie. Pytające sądy nie kwestionowały samej zasadności łączenia kar różnorodzajowych ani regulujących je zasad. Istotą problemu konstytucyjnego była wynikająca z art. 87 $\S 1$ k.k. „obligatoryjność objęcia węzłem kary łącznej kar różnorodzajowych po dokonaniu zamiany kary ograniczenia wolności na karę pozbawienia wolności”.

Wzorcami kontroli w rozpatrywanej sprawie były art. 45 ust. 1 i art. 175 ust. 1 Konstytucji RP. Pierwszy z przepisów przewiduje, że „każdy ma prawo do sprawiedliwego i jawnego rozpatrzenia sprawy bez nieuzasadnionej zwłoki przez właściwy, niezależny, bezstronny i niezawisły sąd”. Art. 175 ust. 1 stanowi zaś, że „wymiar sprawiedliwości w Rzeczypospolitej Polskiej sprawują Sąd Najwyższy, sądy powszechne, sądy administracyjne oraz sądy wojskowe".

Trybunał Konstytucyjny słusznie uznał, że wymierzenie kary łącznej w wyroku łącznym stanowi „,sprawę” w rozumieniu art. 45 ust. 1 Konstytucji. Pojęcie „rozpatrzenie sprawy", zawarte w art. 45 ust. 1 ustawy zasadniczej, jest ściśle związane z pojęciem „wymiar sprawiedliwości” i obejmuje „wszelkie sytuacje, w których pojawia się konieczność rozstrzygnięcia o prawach danego podmiotu w relacji z innymi równorzędnymi podmiotami lub w relacji z władzą publiczną, w tym również konieczność rozstrzygnięcia o zasadności zarzutów karnych i wymierzania kar"».

Standard konstytucyjny wymaga przy rozpatrywaniu ,sprawy” w znaczeniu art. 45 ust. 1 Konstytucji i ,wymierzeniu sprawiedliwości” w rozumieniu art. 175 ust. 1 Konstytucji zachowania minimum kompetencji sądu. Ustawodawca powinien pozostawić sądowi orzekającemu o pozbawieniu wolności pewien zakres swobody decyzyjnej, możliwość oceny okoliczności konkretnej sprawy. Tymczasem art. 87 $\S 1$ k.k. w sytuacji, gdy niemożliwe jest zastosowanie art. $87 \S 2$ k.k., zobowiązuje sąd do zamiany kary nieizolacyjnej na izolacyjną i wymierzenia jako kary łącznej kary izolacyjnej. Sprowadza zatem funkcję „,rozpatrzenia” sprawy i „wymierzania sprawiedliwości" do automatycznego, technicznego przeliczenia kary ograniczenia wolności na karę pozbawienia wolności i wymierzenia kary łącznej pozbawienia wolności. Procedowanie, które polega na mechanicznym wykonywaniu woli ustawodawcy, traci cechy właściwe sprawowaniu wymiaru sprawiedliwości ${ }^{5}$.

Trybunał przypomniał, że kara pozbawienia wolności jest karą najbardziej dolegliwą, łączy się z pozbawieniem jednostki wolności osobistej, która stanowi jedną z podstawowych wolności chronionych konstytucyjnie. W licznych orzeczeniach

4 Zob. także wyroki TK: z dnia 13 marca 2012 r., P 39/10, OTK ZU-A 2012, nr 3, poz. 26; z dnia 10 maja 2000 r., K 21/99, OTK ZU 2000, nr 4, poz. 109; z dnia 24 października 2007 r., SK 7/06, OTK ZU-A 2007, nr 9, poz. 108.

5 P. Daniluk, Konstytucyjne prawa do sadu oraz do obrony a obligatoryjne zarzadzenie wykonania kary, „Ius Novum” 2011, nr 2, s. 56-57. 
Trybunał konsekwentnie wskazywał, że „wolność osobista człowieka należy do najbardziej fundamentalnych praw"6. Pozbawienie wolności stanowi ultima ratio. W wyroku z dnia 17 lipca 2013 r. Trybunał Konstytucyjny podkreślił:

Jednym z najważniejszych elementów gwarantujących to, że do pozbawienia wolności jednostki dochodzi tylko w warunkach szczególnie uzasadnionych, jest ustawowa gwarancja pełnej, realnej sądowej - a zatem procesowej kontroli - nad potrzebą pozbawienia wolności jednostki. Wyklucza to konstytucyjną dopuszczalność pozbawienia wolności z mocy prawa. $\mathrm{Z}$ tego punktu widzenia ograniczeniem zakresu procesowych gwarancji byłoby wyłączenie realnej roli sądu z podejmowania decyzji o pozbawieniu jednostki wolności osobistej, nawet jeżeli - formalnie - decyzję w tym zakresie podejmowałby sąd, ale sprowadzony do roli notarialnej ${ }^{7}$.

Trafna jest konkluzja Trybunału, że „obligatoryjność i automatyzm mechanizmu przewidzianego $\mathrm{w}$ art. $87 \S 1$ prowadzą $\mathrm{w}$ istocie do wyłączenia sądowej gwarancji kontroli merytorycznej przesłanek pozbawienia wolności”. Trybunał słusznie podkreślił, powołując się na wyrok z dnia 4 lipca 2018 r. ${ }^{8}$, że wymierzenie kary łącznej nie jest operacją „czysto matematyczną”, lecz wymaga dokonania oceny przez sąd całokształtu działalności przestępczej sprawcy i podjęcia decyzji co do rodzaju i wymiaru kary w granicach przewidzianych w ustawie. Z perspektywy sprawcy jest to nowa „kara” zastępująca wcześniejsze9.

$\mathrm{Na}$ aprobatę zasługuje także pogląd Trybunału Konstytucyjnego, że wymierzaniu kary łącznej w wyroku łącznym powinien towarzyszyć taki sam standard ochrony konstytucyjnej jak podczas wymierzania kar jednostkowych za zbiegające się przestępstwa. Gwarancje wynikające $\mathrm{z}$ art. 41, art. 45 ust. $1 \mathrm{i}$ art. 175 ust. 1 Konstytucji, z których korzystał skazany przy orzekaniu kar jednostkowych, stają się iluzoryczne, jeśli nie może korzystać z nich przy wydawaniu wyroku łącznego, który jest obecnie obligatoryjny i w którym sąd zobowiązany jest do zamiany orzeczonych kar jednostkowych o charakterze wolnościowym na karę izolacyjną i wymierzenie tej ostatniej jako kary łącznej.

Trybunał słusznie skonkludował, że wydawanie wyroku łącznego stanowi sprawowanie wymiaru sprawiedliwości w rozumieniu art. 175 ust. 1 Konstytucji i sądy powinny mieć zapewnioną pewną swobodę orzekania w tym zakresie. Art. $87 \S 1$ k.k. ogranicza tę swobodę w stopniu naruszającym zasadę z art. 175 ust. 1 ustawy zasadniczej.

6 Wyrok TK z dnia 17 lipca 2013 r., SK 9/10, OTK ZU-A 2013, nr 6, poz. 79, a także powołane w tym orzeczeniu: wyrok TK z dnia 1 marca 2011 r., P 21/09, OTK ZU-A 2011, nr 2, poz. 7, cz. III, pkt 4.2.2.5; wyrok TK z dnia 11 czerwca 2002 r., SK 5/02, OTK ZU-A 2002, nr 4, poz. 41, cz. III, pkt 3; wyrok TK z dnia 10 czerwca 2008 r., SK 17/07, OTK ZU-A 2008, nr 5, poz. 78, cz. III, pkt 5.1.

Wyrok TK z dnia 17 lipca 2013 r., SK 9/10, OTK ZU-A 2013, nr 6, poz. 79.

8 Wyrok pełnego składu TK z dnia 4 lipca 2018 r., K 16/16, OTK ZU-A 2018, poz. 52.

9 Ibidem. 
Decyzja o wymiarze i rodzaju kary łącznej nie może być automatyczna, powinna uwzględniać różne okoliczności, być zindywidualizowana i dostosowana do konkretnego przypadku. Nie sposób in abstracto wyliczyć okoliczności świadczące o tym, że zamiana kary ograniczenia wolności na karę pozbawienia wolności i wymierzenie kary łącznej pozbawienia wolności byłoby w konkretnym przypadku niesłuszne. Przykładem może być stan faktyczny sprawy, w której przedstawiono pytanie prawne. Skazany w czasie postępowania w przedmiocie wyroku łącznego został warunkowo przedterminowo zwolniony z odbywania podlegającej łączeniu kary pozbawienia wolności, przebywał w miejscu zamieszkania i odbywał karę 2 lat ograniczenia wolności. W takiej sytuacji obligatoryjny mechanizm z art. 87 $\S 1$ k.k., który nakazuje automatycznie przerwać karę ograniczenia wolności, którą skazany sumiennie odbywa, wymierzyć karę łączną pozbawienia wolności, izolując skazanego przez dłuższy okres w środowisku o wysokim stopniu demoralizacji, bez możliwości uwzględnienia postawy skazanego, prognozy kryminologicznej dokonanej przez sąd, który orzekał karę ograniczenia wolności, a także wychowawczego efektu pracy społecznej wykonywanej w ramach kary ograniczenia wolności, narusza standard konstytucyjny, co zostało słusznie podkreślone przez pytające sądy. Przykłady, w których automatyczna zamiana kary ograniczenia wolności na karę pozbawienia wolności jest niecelowa i krzywdząca, można mnożyć. Tym bardziej, że w świetle badań empirycznych efekt resocjalizacyjny kary pozbawienia wolności jest wysoce niezadowalający ${ }^{10}$.

Glosowane orzeczenie ma charakter zakresowy, co zdeterminowane było treścią pytań prawnych. Sądy pytające wskazały tylko zakres normy jako przedmiot kontroli, wobec czego Trybunał Konstytucyjny musiał orzec zakresowo ${ }^{11}$.

Skutkiem orzeczenia nie jest eliminacja art. $87 \S 1$ k.k., lecz stworzenie odstępstwa od imperatywnego charakteru przepisu i wprowadzenie do niego fakultatywności. Na podstawie glosowanego wyroku z dniem 18 czerwca 2019 r. art. 87 $\S 1$ k.k. utracił moc w zakresie, w jakim nakłada na sąd obowiązek połączenia kar pozbawienia wolności i ograniczenia wolności oraz wymierzenia kary łącznej pozbawienia wolności po dokonaniu zamiany kary ograniczenia wolności na karę pozbawienia wolności.

Obecnie sądy, rozpatrując sprawę zbiegu skazań na kary pozbawienia wolności i ograniczenia wolności, nie mają obowiązku stosować reguły z art. $87 \S 1$ k.k. Wydaje się zatem, że sąd wydający wyrok łączny w przypadku, gdy za zbiegające się przestępstwa wymierzono kary pozbawienia i ograniczenia wolności, powinien rozważyć możliwość zastosowania art. 87 § 2 k.k. W przypadku gdy nie jest możli-

10 Zob. wyrok TK z dnia 17 lipca 2013 r., SK 9/10, OTK ZU-A 2013, nr 6, poz. 79 oraz przytoczoną tam opinię T. Szymanowskiego z 12 lipca $2012 \mathrm{r}$.

${ }_{11}$ Zob. M. Jackowski, Nastęstwa wyroków Trybunału Konstytucyjnego w procesie sądowego stosowania prawa, Warszawa 2016, passim. 
we lub nie jest zasadne skorzystanie z art. 87 § 2 k.k., można zastosować regulację $\mathrm{z}$ art. $87 \S 1$ k.k. lub nie stosować jej i umorzyć postępowanie w tym zakresie na podstawie art. 572 k.p.k. W sprawach, w których łączeniu podlega większa liczba kar, może dojść do połączenia kar jednorodzajowych (kar pozbawienia wolności i osobno kar ograniczenia wolności). Przypomnieć należy, że zgodnie z art. 190 ust. 4 Konstytucji orzeczenie Trybunału Konstytucyjnego o niezgodności z ustawą zasadniczą aktu normatywnego, na podstawie którego zostało wydane prawomocne orzeczenie sądowe, stanowi podstawę do wznowienia postępowania. Skazani, wobec których zastosowano art. $87 \S 1$ k.k. przed orzeczeniem Trybunału Konstytucyjnego, mogą skorzystać z mechanizmu wzruszenia prawomocnego orzeczenia na podstawie art. $540 \S 2$ k.p.k.

Jeżeli chodzi o postulaty de lege ferenda, należałoby podjąć działania prawodawcze uwzględniające rozstrzygnięcie Trybunału Konstytucyjnego. Zmiana może polegać na zastąpieniu wyrażenia ,sąd wymierza” zwrotem „sąd może wymierzyć”. W planowanej nowelizacji Kodeksu karnego (ustawie z dnia 13 czerwca 2019 r. o zmianie ustawy - Kodeks karny oraz niektórych innych ustaw, którą Prezydent RP przekazał do Trybunału Konstytucyjnego) nie przewidziano modyfikacji art. 87 k.k. De lege ferenda rozważać można także całkowite uchylenie art. 87 k.k.

Na marginesie glosowanego orzeczenia warto jeszcze poczynić pewną uwagę. Otóż przepis o treści, która obecnie ujęta jest w art. $87 \S 1$ k.k., obowiązuje w polskim porządku prawnym od ponad 50 lat - od wejścia w życie Kodeksu karnego z 1969 r. Jego ratio legis od początku mogło budzić wątpliwości, a po wprowadzeniu w 2015 r. do Kodeksu karnego sekwencji kar z art. 37b uległo dezaktualizacji ${ }^{12}$. Należy zadać fundamentalne pytanie o to, jakie jest uzasadnienie obowiązku łączenia kar pozbawienia i ograniczenia wolności poprzez zamianę kary nieizolacyjnej na izolacyjną. Wprowadzając art. 69 w k.k. z 1969 r., który był poprzednikiem art. $87 \S 1$ k.k. i miał niemal identyczne brzmienie, wskazywano, że:

[...] przy zbiegu kary pozbawienia wolności z karą ograniczenia wolności kodeks przewiduje wymierzenie łącznej kary pozbawienia wolności (art. 69), wychodząc z założenia, że przy skazaniu sprawcy na podlegającą wykonaniu karę pozbawienia wolności odpadają względy, którymi kieruje się kodeks, wprowadzając do katalogu kar zasadniczych karę ograniczenia wolności ${ }^{13}$.

Także w doktrynie podkreślano, że wymierzone jednocześnie kary pozbawienia i ograniczenia wolności należy połączyć, ,albowiem wobec perspektywy wykonania kary pozbawienia wolności odpada racja bytu kary ograniczenia wolności, jako kary wykonywanej bez osadzenia w zakładzie karnym w dotychczasowych warun-

${ }_{12}$ Zob. A. Nowosad, O potrzebie uchylenia art. 87 Kodeksu karnego, „Studia Iuridica Lublinensia" 2017, nr 2, DOI: http://dx.doi.org/10.17951/sil.2017.26.2.77, s. 77-85.

13 Uzasadnienie projektu kodeksu karnego oraz przepisów wprowadzających kodeks karny, Warszawa 1969, s. 117. 
kach skazanego, a więc na wolności"'14. Warto przypomnieć, że karę ograniczenia wolności wprowadził Kodeks karny z 1969 r. ${ }^{15}$ Jej celem miało być zastąpienie wymierzanych zbyt często w praktyce krótkoterminowych kar pozbawienia wolności ${ }^{16}$. Wskazywano, że zaletą kary ograniczenia wolności jest to, że skazany nie odbywa jej w zamkniętym zakładzie, lecz pozostaje w społeczeństwie, najczęściej we własnym środowisku, dzięki czemu nie styka się ze środowiskiem przestępczym zakładu karnego ${ }^{17}$. Pierwotnie zatem uzasadnieniem omawianej regulacji było przekonanie, że racją bytu kary ograniczenia wolności jest jej wolnościowy charakter - to, że skazany nie jest narażony na demoralizujący wpływ środowiska przestępczego zakładu karnego. Tymczasem w przypadku, gdy ktoś jest i tak skazany na bezwzględną karę pozbawienia wolności i trafi do zakładu karnego, cele kary ograniczenia wolności, która zakłada uchronienie skazanego przed negatywnym wpływem środowiska przestępczego zakładu karnego, nie zostaną osiągnięte.

$\mathrm{Na}$ gruncie obowiązującego Kodeksu karnego jako ratio legis art. 87 k.k. zawsze wskazywano brak możliwości równoczesnego wykonywania kar pozbawienia wolności i ograniczenia wolności. W piśmiennictwie i judykaturze jednomyślnie uznawano, że art. 87 k.k. (obecny art. $87 \S 1$ k.k.) wprowadza wyjątek od zasady łączenia kar tego samego rodzaju, uzasadniony brakiem możliwości równoczesnego wykonywania kary pozbawienia wolności oraz kary ograniczenia wolności ${ }^{18}$.

Reforma prawa karnego, która weszła w życie 1 lipca 2015 r. ${ }^{19}$, przyjęła całkowicie odmienne założenia dotyczące kary ograniczenia wolności. Wprowadzenie w art. $37 \mathrm{~b}$ k.k. sekwencji kar ograniczenia i pozbawienia wolności oznacza, że kara ograniczenia wolności przestała być tylko alternatywą dla kary pozbawienia wolności, orzekaną na zasadzie „albo jedna, albo druga”, lecz stała się także jej uzupełnieniem - karą, która może być wymierzona obok kary izolacyjnej. W uzasadnieniu projektu ustawy z dnia 20 lutego 2015 r. wskazano, że uzupełnieniem

${ }_{14}$ M. Siewierski, [w:] J. Bafia, K. Mioduski, M. Siewierski, Kodeks karny. Komentarz, Warszawa 1977, s. 234.

${ }^{15}$ Kara ograniczenia wolności wcześniej nie była znana polskiemu ustawodawstwu, jedynie w latach 1950-1959 istniała kara pracy poprawczej.

16 Uzasadnienie projektu kodeksu karnego..., s. 107.

${ }_{17}$ W. Świda, [w:] I. Andrejew, W. Świda, W. Wolter, Kodeks karny z komentarzem, Warszawa 1973, s. 176.

18 Wyrok SN z dnia 9 lipca 2003 r., III KK 276/03, Prok. i Pr. (wkł.) 2004, nr 2, poz. 1; L. Tyszkiewicz, [w:] M. Kalitowski, Z. Sienkiewicz, J. Szumski, L. Tyszkiewicz, A. Wąsek, Kodeks karny. Komentarz, Gdańsk 2005, s. 266; P. Kardas, [w:] Kodeks karny - część ogólna. Komentarz, red. A. Zoll, Kraków 2004, s. 1156; J. Giezek, [w:] Kodeks karny. Część ogólna. Komentarz, red. J. Giezek, LEX/el. 2012, s. 554, P. Kozłowska-Kalisz, [w:] Kodeks karny. Komentarz, red. M. Mozgawa, Warszawa 2013, s. 216; S. Żółtek, [w:] Kodeks karny. Część ogólna. Komentarz, red. M. Królikowski, R. Zawłocki, t. 2, Warszawa 2011, s. 749.

19 Ustawa z dnia 20 lutego 2015 r. o zmianie ustawy - Kodeks karny oraz niektórych innych ustaw (Dz.U. 2015, poz. 396). 
oddziaływania penalnego krótkoterminowej kary izolacyjnej mogłaby być kara ograniczenia wolności, która skierowana byłaby ku ugruntowaniu społecznie pożądanych zachowań skazanego, a jednocześnie pozbawiona byłaby tak silnego stygmatyzującego skutku ${ }^{20}$. Reforma lipcowa prawa karnego całkowicie zerwała zatem z założeniami, które legły u podstaw wprowadzenia regulacji z art. 69 k.k. z 1969 r. i art. 87 § 1 k.k. Konsekwentnie ustawodawca powinien był uchylić art. 87 k.k. Skoro bowiem przyjął, że słuszne jest orzekanie jednoczesne obu kar i kolejne ich wykonywanie, to dlaczego przy karze łącznej pozostawił obowiązek zamiany kary ograniczenia wolności na karę pozbawienia wolności? Nowelizując kodeks, uznano, że następujące po sobie wykonywanie kary pozbawienia wolności i ograniczenia wolności powinno uzupełniać „oddziaływanie penalne” kary izolacyjnej i służyć „,ugruntowaniu społecznie pożądanych zachowań skazanego”, lecz w przypadku, gdy ktoś jest skazany za zbiegające się przestępstwa na obie kary, obligatoryjna jest zamiana jednej kary na drugą i wykonanie tylko kary pozbawienia wolności. Dodatkowo uzasadnia się to niemożnością równoczesnego wykonania obu kar, podczas gdy w świetle nowych założeń kary te powinno się wykonywać oddzielnie, jedna po drugiej, co ma wzajemnie uzupełniać i wzmagać ich oddziaływanie.

Pomimo oczywistych, istniejących od samego początku, wad przepisu regulującego łączenie kar pozbawienia i ograniczenia wolności, dopiero w ostatnim okresie do Trybunału wpłynęły pytania prawne dotyczące jego konstytucyjności ${ }^{21}$. Uważam, że powodem tego, iż dopiero teraz w praktyce sądowej dostrzeżono mankamenty regulacji, było zwiększenie liczby tego typu spraw, spowodowane wprowadzeniem w 2015 r. nowego modelu kary łącznej oraz art. 12b k.k.w. ${ }^{22}$ Art. $12 b$ k.k.w., na pierwszy rzut oka mający charakter jedynie techniczny czy porządkujący, sprawił, że art. 87 k.k. zaczął być zdecydowanie częściej stoso-

${ }^{20}$ Uzasadnienie rządowego projektu ustawy o zmianie ustawy - Kodeks karny oraz niektórych innych ustaw z projektami aktów wykonawczych z 15 maja 2014 r., Druk nr 2393, http://orka.sejm.gov. pl/Druki7ka.nsf/0/39FD209B7AC6C45AC1257CDE0042D631/\%24File/2393-uzas.docx [dostęp: 10.05.2020], s. 11-12.

${ }^{21} \mathrm{~W}$ doktrynie T. Sroka (Konstytucyjne aspekty kary łacznej. Zagadnienia wybrane, [w:] Zagadnienia teorii i nauczania prawa karnego. Kara łączna. Księga jubileuszowa Profesor Marii Szewczyk, red. W. Górowski, P. Kardas, T. Sroka, W. Wróbel, Warszawa 2013, s. 547-555) podał W wątpliwość zgodność regulacji z art. 87 k.k. ze standardami konstytucyjnymi. Proponowano także, aby wprowadzić w art. 87 k.k. możliwość orzeczenia jako kary łącznej kary ograniczenia wolności. Zob. J. Giezek, op. cit., s. 553; D. Kala, M. Klubińska, Kara łączna w projektach nowelizacji Kodeksu karnego - wybrane zagadnienia, „Kwartalnik Krajowej Szkoły Sądownictwa i Prokuratury” 2014, nr 13, s. 107. Krytycznie o przepisie także: A. Dziergawka, Kontrowersje dotyczace łaczenia kar pozbawienia wolności i ograniczenia wolności (art. 87 \& 1 i 2 k.k.), „Prokuratura i Prawo” 2019, nr 10, s. 42-65.

${ }^{22}$ Ustawa z dnia 20 lutego 2015 r. o zmianie ustawy - Kodeks karny oraz niektórych innych ustaw (Dz.U. 2015, poz. 396). 
wany, co obnażyło jego wady ${ }^{23}$. Przed wprowadzeniem art. 12b k.k.w. skazani na karę pozbawienia wolności i ograniczenia wolności przypuszczalnie rzadko występowali z wnioskami o wydanie wyroku łącznego, gdyż było to dla nich niekorzystne i art. 87 k.k. mógł nie mieć w praktyce tak częstego zastosowania ${ }^{24}$. Po wprowadzeniu art. 12b k.k.w. wszystkie organy wykonujące orzeczenie mają obowiązek niezwłocznego zawiadomienia właściwego sądu, że zachodzą warunki do wydania wyroku łącznego, a prezes sądu wszczyna zarządzeniem postępowanie o wydanie wyroku łącznego, co oznacza, że postępowanie toczy się zasadniczo w każdej sprawie ${ }^{25}$.

\section{BIBLIOGRAFIA}

\section{Literatura}

Daniluk P., Konstytucyjne prawa do sadu oraz do obrony a obligatoryjne zarządzenie wykonania kary, „Ius Novum” 2011, nr 2.

Dziergawka A., Kontrowersje dotyczące łączenia kar pozbawienia wolności i ograniczenia wolności (art. 87 \& 1 i 2 k.k.), „Prokuratura i Prawo” 2019, nr 10.

Giezek J., [w:] Kodeks karny. Czesść ogólna. Komentarz, red. J. Giezek, LEX/el. 2012.

Jackowski M., Następstwa wyroków Trybunału Konstytucyjnego w procesie sądowego stosowania prawa, Warszawa 2016.

Kala D., Klubińska M., Kara łączna w projektach nowelizacji Kodeksu karnego - wybrane zagadnienia, „Kwartalnik Krajowej Szkoły Sądownictwa i Prokuratury” 2014, nr 13.

Kardas P., [w:] Kodeks karny - część ogólna. Komentarz, red. A. Zoll, Kraków 2004.

Kardas P., [w:] Kodeks karny. Część ogólna, t. 1: Komentarz do art. 53-116, red. W. Wróbel, A. Zoll, Warszawa 2016.

Kozłowska-Kalisz P., [w:] Kodeks karny. Komentarz, red. M. Mozgawa, Warszawa 2013.

${ }^{23}$ Zob. A. Nowosad, Drobna zmiana o dużym znaczeniu - art. 12 b Kodeksu karnego wykonawczego, „Państwo i Prawo” 2018, z. 7, s. 82-90.

${ }^{24}$ Przed wejściem w życie art. $12 \mathrm{~b}$ k.k.w. postępowania w sprawie wydania wyroku łącznego mogły być inicjowane na wniosek stron i z urzędu. Wydaje się jednak, że dominowały postępowania na wniosek skazanego, a postępowania z urzędu lub na wniosek prokuratora nie były zbyt częste. Przykładowo z badań M. Kulika wynika, że wśród przeanalizowanych 512 postępowań w sprawie wyroku łącznego rozpoznanych w latach 2012-2013 z urzędu wszczęto 1,6\% spraw, na wniosek skazanego - 94,5\% spraw, a na wniosek obrońcy - 4,2\% spraw. Znakomita większość postępowań była zatem wszczęta na wniosek skazanego lub jego obrońcy, postępowania z urzędu stanowiły niewielki odsetek, a przypadków wszczęcia postępowania na wniosek prokuratora w ogóle nie było. Zob. M. Kulik, Wyrok taczny w praktyce sądowej w latach 2012-2013, „Prawo w Działaniu” 2015, nr 23, s. 182.

${ }^{25}$ Zob. obecnie § 299 ust. 2 rozporządzenia Ministra Sprawiedliwości z dnia 18 czerwca 2019 r. - Regulamin urzędowania sądów powszechnych (Dz.U. 2019, poz. 1141), wcześniej § 274 ust. 2 rozporządzenia Ministra Sprawiedliwości z dnia 23 grudnia 2015 r. - Regulamin urzędowania sądów powszechnych (Dz.U. 2015, poz. 2316). 
Kulik M., Wyrok łączny w praktyce sadowej w latach 2012-2013, „Prawo w Działaniu” 2015, nr 23. Majewski J., Kodeks karny. Komentarz do zmian 2015, Warszawa 2015.

Nowosad A., Drobna zmiana o dużym znaczeniu - art. 12 b Kodeksu karnego wykonawczego, „Państwo i Prawo" 2018, z. 7.

Nowosad A., O potrzebie uchylenia art. 87 Kodeksu karnego, „Studia Iuridica Lublinensia” 2017, nr 2, DOI: http://dx.doi.org/10.17951/sil.2017.26.2.77.

Siewierski M., [w:] J. Bafia, K. Mioduski, M. Siewierski, Kodeks karny. Komentarz, Warszawa 1977.

Sroka T., Konstytucyjne aspekty kary tącznej. Zagadnienia wybrane, [w:] Zagadnienia teorii i nauczania prawa karnego. Kara łączna. Księga jubileuszowa Profesor Marii Szewczyk, red. W. Górowski, P. Kardas, T. Sroka, W. Wróbel, Warszawa 2013.

Świda W., [w:] I. Andrejew, W. Świda, W. Wolter, Kodeks karny z komentarzem, Warszawa 1973.

Tyszkiewicz L., [w:] M. Kalitowski, Z. Sienkiewicz, J. Szumski, L. Tyszkiewicz, A. Wąsek, Kodeks karny. Komentarz, Gdańsk 2005.

Uzasadnienie projektu kodeksu karnego oraz przepisów wprowadzających kodeks karny, Warszawa 1969.

Uzasadnienie rzadowego projektu ustawy o zmianie ustawy - Kodeks karny oraz niektórych innych ustaw z projektami aktów wykonawczych z 15 maja 2014 r., Druk nr 2393, http://orka.sejm. gov.pl/Druki7ka.nsf/0/39FD209B7AC6C45AC1257CDE0042D631/\%24File/2393-uzas.docx [dostęp: 10.05.2020].

Żółtek S., [w:] Kodeks karny. Część ogólna. Komentarz, red. M. Królikowski, R. Zawłocki, t. 2, Warszawa 2011.

\section{Akty prawne}

Rozporządzenie Ministra Sprawiedliwości z dnia 23 grudnia 2015 r. - Regulamin urzędowania sądów powszechnych (Dz.U. 2015, poz. 2316).

Rozporządzenie Ministra Sprawiedliwości z dnia 18 czerwca 2019 r. - Regulamin urzędowania sądów powszechnych (Dz.U. 2019, poz. 1141).

Ustawa z dnia 20 lutego 2015 r. o zmianie ustawy - Kodeks karny oraz niektórych innych ustaw (Dz.U. 2015, poz. 396).

\section{Orzecznictwo}

Wyrok SN z dnia 2 września 1975 r., IV KRN 52/75, OSNKW 1976, nr 3, poz. 44.

Wyrok SN z dnia 9 lipca 2003 r., III KK 276/03, Prok. i Pr. (wkł.) 2004, nr 2, poz. 1.

Wyrok TK z dnia 10 maja 2000 r., K 21/99, OTK ZU 2000, nr 4, poz. 109.

Wyrok TK z dnia 11 czerwca 2002 r., SK 5/02, OTK ZU-A 2002, nr 4, poz. 41.

Wyrok TK z dnia 24 października 2007 r., SK 7/06, OTK ZU-A 2007, nr 9, poz. 108.

Wyrok TK z dnia 10 czerwca 2008 r., SK 17/07, OTK ZU-A 2008, nr 5, poz. 78.

Wyrok TK z dnia 1 marca 2011 r., P 21/09, OTK ZU-A 2011, nr 2, poz. 7.

Wyrok TK z dnia 13 marca 2012 r., P 39/10, OTK ZU-A 2012, nr 3, poz. 26.

Wyrok TK z dnia 17 lipca 2013 r., SK 9/10, OTK ZU-A 2013, nr 6, poz. 79.

Wyrok pełnego składu TK z dnia 4 lipca 2018 r., K 16/16, OTK ZU-A 2018, poz. 52.

Wyrok TK z dnia 11 czerwca 2019 r., P 20/17, OTK-A 2019, poz. 29. 
Pobrane z czasopisma Studia Iuridica Lublinensia http://studiaiuridica.umes.pl Data: 26/04/2023 13:58:29

Glosa do wyroku Trybunału Konstytucyjnego z dnia 11 czerwca $2019 \ldots$

\section{SUMMARY}

The author agrees with the Constitutional Tribunal's opinion that Article $87 \S 1$ of the Penal Code to the extent that it imposes an obligation on the court to combine imprisonment and restriction of liberty and to impose a total penalty of deprivation of liberty after converting the penalty of restriction of liberty into imprisonment is inconsistent with the Constitution of the Republic of Poland. In addition, the author raised the problem of ratio legis of Article 87 of the Penal Code and indicated why the deficiencies in regulation were noticed so late in the case law.

Keywords: restriction of liberty; imprisonment; sequence of the penalties; aggregate penalty; concurrent sentence; concurrent offences 